\title{
ACUTE MOUNTAIN SICKNESS; THE EFFECT OF AMMONIUM CHLORIDE ${ }^{1}$
}

\author{
By E. S. GUZMAN BARRON, D. B. DILL, H. T. EDWARDS AND \\ ALBERTO HURTADO \\ (From the Lasker Foundation for Medical Research and the Department of Medicine of the \\ University of Chicago, Chicago; the Fatigue Laboratory, Harvard University, Boston; \\ and the Department of Physiopathology, Facultad de Medicina, Lima, Peru)
}

(Received for publication January 22, 1937)

Our knowledge of the etiology of mountain sickness has not advanced very much since Paul Bert's fundamental observations (1), and little has been added to the understanding of its mechanism.

Detailed descriptions of the symptoms of mountain sickness have been given by those who have studied it, from Acosta in 1569 (2) to Monge et al. in 1928 (3) (Douglas, Haldane et al. (4), Barcroft et al. (5)). Although opinion on the fundamental cause of this disturbance is unanimous, there is disagreement as to the manner in which the organism endeavors to prevent the appearance of mountain sickness. Since this paper deals only with the disturbances produced as a consequence of rapid ascents to high altitudes, it will not discuss either Haldane's secretion theory, which has been shown to be incorrect by the Chilean studies of Dill, Christensen and Edwards (6), or Barcroft's claim (5) that the oxygen dissociation curve of hemoglobin deviates to the left, shown to be incorrect by Keys, Hall and Barron (7) and by Hall (8) on the same expedition. ${ }^{2}$ By most observers the following have been considered processes of adaptation to high altitude: 1 , a rise in the arterial oxygen pressure; 2 , a fall in alveolar $\mathrm{CO}_{2}$ pressure and a corresponding rise in alveolar oxygen pressure; 3 , an increase in the per cent and total amount of the hemoglobin of the blood; 4, an acceleration of the blood flow. Some of these processes will be discussed in the light of our experience during an automobile trip from Lima ( 160 meters) to Ticlio (4740 meters). ${ }^{3}$

\footnotetext{
1 We wish to acknowledge our gratitude to Mr. Harold Kingsmill, General Manager of the Cerro de Pasco Mining Company, for providing facilities for the trip from Lima to Ticlio.

2 These authors give details of financial support and itinerary of the "International High Altitude Expedition."

3 For rapidity of ascent from sea level to great alti-
}

\section{PROCEDURE}

On the day preceding the trip to Ticlio, six men (three medical students and three male nurses) of the twelve who made up the party took 15 grams each of $\mathrm{NH}_{4} \mathrm{Cl}$ in three 5-gram doses before breakfast, lunch, and dinner. On the following day, between 6:10 a.m. and 7:50 a.m., samples of alveolar air, taken at the end of normal expiration, and $50 \mathrm{cc}$. of arterial blood were obtained from each of these six individuals. The party started from Lima in three automobiles at 8:15 a.m., and after two halts (one in San Mateo (3200 meters) for one hour and another in Casapalca (4140 meters) for one and one-half hours) arrived at Ticlio at $4: 15$ p.m. Upon their arrival the party had to walk about 200 meters to the engineer's house, where, after a rest of half an hour, arterial blood and alveolar air were taken from all but two members of the party. (Details concerning the individual reactions of the members of the party to the ascent are given at the end of this paper.)

\section{Arterial oxygen saturation}

Since hemoglobin has been considered the main factor of oxygen transport in mammalians, all investigators have given to its degree of oxygen saturation a rôle of prime importance in the causation of mountain sickness. Since there was no experimental evidence for this claim (no analysis of arterial blood having been performed), "cyanosis" and "blueness of the lips" were given as proof for their contention.

tudes few places in the world can compare with the LimaTiclio region. It is for this reason peculiarly suited to the study of acute mountain sickness. This investigation is really an outcome of conversation on the PanamaCallao voyage with Dr. Crane, Chief Surgeon for the Cerro de Pasco Mining Company. His experiences make him a preeminent authority on the subject of acute mountain sickness. 
TABLE I

Arterial oxygen saturation in acute mountain sickness. Arterial blood taken in Lima (160 meters) in the morning, before the trip, and in Ticlio (4740 meters) in the afternoon of the same day

\begin{tabular}{|c|c|c|c|c|c|}
\hline \multirow{2}{*}{ Name } & \multicolumn{2}{|c|}{ Lima } & \multicolumn{2}{|c|}{ Ticlio } & \multirow{2}{*}{ Condition } \\
\hline & $\begin{array}{c}\mathrm{HbO}_{2} \\
\text { con- } \\
\text { tent }\end{array}$ & $\begin{array}{l}\mathrm{HbO}_{2} \\
\text { satu- } \\
\text { ration }\end{array}$ & $\begin{array}{l}\mathrm{HbO}_{2} \\
\text { con- } \\
\text { tent }\end{array}$ & $\begin{array}{l}\mathrm{HbO}_{2} \\
\text { satu- } \\
\text { ration }\end{array}$ & \\
\hline 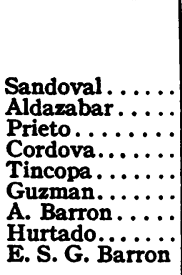 & $\begin{array}{l}\operatorname{mM} . \\
\text { per } \\
\text { liter } \\
9.54 \\
9.71 \\
8.24 \\
9.24 \\
8.04\end{array}$ & $\begin{array}{l}\text { per } \\
\text { cent } \\
92.0 \\
92.6 \\
92.7 \\
91.6 \\
93.7\end{array}$ & $\begin{array}{c}\text { mM. } \\
\text { per } \\
\text { liter } \\
7.67 \\
7.49 \\
8.24 \\
6.44 \\
8.12 \\
6.48 \\
6.17 \\
8.07 \\
8.05\end{array}$ & $\begin{array}{l}\text { per } \\
\text { cent } \\
74.6 \\
70.3 \\
81.7 \\
72.9 \\
78.7 \\
73.8 \\
65.4 \\
75.3 \\
73.3\end{array}$ & $\begin{array}{l}\text { Ill. Mountain sickness } \\
\text { IIl. Mountain sickness } \\
\text { III. Mountain sickness } \\
\text { Good } \\
\text { Good } \\
\text { Good } \\
\text { Good } \\
\text { Good } \\
\text { Good }\end{array}$ \\
\hline \multicolumn{4}{|c|}{ 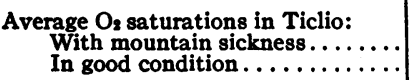 } & $\begin{array}{l}75.5 \\
73.2\end{array}$ & \\
\hline \multicolumn{4}{|c|}{$\begin{array}{r}\text { Average } \mathrm{O}_{2} \text { saturation at Montt (4710 } \\
\text { meters) acclimatized members } \\
\text { of the Chilean Expedition...... }\end{array}$} & 78.0 & \\
\hline
\end{tabular}

In Table I are given the oxygen saturation and content of the arterial blood of the members of the party, as taken in Lima and in Ticlio. The average oxygen saturation of the individuals with mountain sickness was 75.5 per cent, while that of the individuals who did not feel any ill effects at this altitude was 73.2 per cent. Prieto, with an arterial oxygen saturation of 81.7 per cent, was ill; while A. Barron, with an oxygen saturation of 65.4 per cent, was well. Similar results were found earlier in Chile. In Montt, at 4710 meters, only 30 meters lower than Ticlio, Dill, with an arterial oxygen saturation of 71.6 per cent, was working with normal efficiency; while Hall, with an oxygen saturation of 83.2 per cent, had a mild case of mountain sickness (headache, lack of appetite, nausea).

\section{Hemoglobin concentration}

Barcroft (9), in his excellent studies on the physiology of the spleen, considers this organ as one of the main storehouses or depots for blood, adding as others the liver, lungs, and subpapillary vessels of the skin. The rôle of the spleen as a blood reservoir which the organism may utilize in case of need seems to vary in the different animal species. For example, while the dog's spleen, according to Barcroft, raises by its contraction during exercise the oxygen capacity of the blood, such a rise does not occur in man (Dill, Talbott and Edwards (10)). It could be argued that during the ascent to high altitudes, before there is an increase in hemoglobin formation these blood reservoirs throw into the general circulation their reserve red cells, thus increasing the oxygen capacity of the blood. In Table II is given the oxygen capacity (a more reliable figure than the red cell count) of those members of the party whose arterial blood was obtained at both places, Lima and Ticlio. There was essentially no difference between the average arterial oxygen capacity in Lima, $9.68 \mathrm{mM}$. per liter, and that in Ticlio, $9.76 \mathrm{mM}$. per liter. Although there was a slightly higher average increase in the oxygen capacity of those who felt no ill symptoms than of those who suffered mountain sickness, the difference is too small to deserve attention. We may therefore conclude that these "blood stores" play no important function in the rapid adjustments of the organism to high altitudes. For comparison we have added the oxygen capacity of the acclimatized members of the Chilean Expedition after a gradual ascent to Montt, practically the same altitude as Ticlio. Here the increase in hemoglobin concentration is evident.

TABLE II

Arterial oxygen capacity soon after an ascent to high altitudes (Ticlio, 4740 meters)

\begin{tabular}{|c|c|c|c|}
\hline \multirow{2}{*}{ Name } & \multicolumn{2}{|c|}{$\begin{array}{c}\text { Oxygen } \\
\text { capacity }\end{array}$} & \multirow{2}{*}{ Condition in Ticlio } \\
\hline & $\underset{\text { Lima }}{\text { In }}$ & $\underset{\text { Ticlio }}{\text { In }}$ & \\
\hline $\begin{array}{l}\text { Sandoval . . . . . . . } \\
\text { Cordova . . . . . . } \\
\text { Aldazabar . . . . . . } \\
\text { Tincopa . . . . . . . } \\
\text { Guzman }\end{array}$ & $\begin{array}{r}\underset{c}{m M .} \\
\text { per } \\
\text { liter } \\
10.37 \\
8.90 \\
10.48 \\
10.10 \\
8.58\end{array}$ & $\begin{array}{r}\text { mM. } \\
\text { per } \\
\text { liter } \\
10.25 \\
8.82 \\
10.65 \\
10.30 \\
8.77\end{array}$ & \multirow[t]{5}{*}{$\begin{array}{l}\text { Ill. Mountain sickness } \\
\text { Good } \\
\text { Ill. Mountain sickness } \\
\text { Good } \\
\text { Good }\end{array}$} \\
\hline Average . . . . . . . & 9.68 & 9.76 & \\
\hline \multirow[t]{2}{*}{$\begin{array}{l}\text { Ill, mountain sick- } \\
\text { ness............ } \\
\text { In good condition. }\end{array}$} & $\begin{array}{r}10.42 \\
9.19\end{array}$ & $\begin{array}{r}10.45 \\
9.30\end{array}$ & \\
\hline & $\begin{array}{c}\text { Boston } \\
\text { (sea } \\
\text { level) }\end{array}$ & \begin{tabular}{|c} 
Montt \\
$(4710$ \\
meters
\end{tabular} & \\
\hline $\begin{array}{l}\text { Members of the } \\
\text { Chilean Expedi- } \\
\text { tion........... }\end{array}$ & 8.84 & 10.72 & \\
\hline
\end{tabular}


Pressure of oxygen in alveolar air. Effect of $\mathrm{NH}_{4} \mathrm{Cl}$

A rise in the pressure of oxygen in the alveolar air, accomplished by an increase in the total ventilation, has been considered as one of the mechanisms of adaptation. Furthermore, Haldane and Priestley (11) state that " the diminution in available alkali seems to be much more important" for the process of adaptation to high altitudes. They then add, "Possibly this part of acclimatization might be greatly hastened by the administration of $\mathrm{NH}_{4} \mathrm{Cl}$ " $(11, \mathrm{p} .317)$. If an increase in the pressure of oxygen of the alveolar air may prevent mountain sickness, Haldane's suggestion seemed reasonable. Greene, during the expedition to Mount Kamet (12), took small doses of $\mathrm{NH}_{4} \mathrm{Cl}$ ( 0.45 gram three times daily) and thought that the effect was beneficial. Later, Douglas, Greene and Kergin (13) compared the general condition and capacity to do muscular work of one subject at a pressure of $347 \mathrm{~mm}$. $\mathrm{Hg}$ in a steel chamber with and without the administration of $\mathrm{NH}_{4} \mathrm{Cl}$. With $\mathrm{NH}_{4} \mathrm{Cl}$ the subject showed a lower alveolar $\mathrm{CO}_{2}$ pressure and a higher oxygen pressure, a lessened degree of cyanosis, a slower pulse rate, and a greater ability to perform muscular work than in experiments in which no $\mathrm{NH}_{4} \mathrm{Cl}$ had been taken. According to Fölling (14) the increase in alveolar ventilation after ingestion of $\mathrm{NH}_{4} \mathrm{Cl}$ over a two-day period is not proportionate to the decrease in alkaline reserve, the result being an uncompensated acidosis.

The fact that there is no relation, down to certain limits, between the arterial oxygen saturation and mountain sickness raises strong doubts as to the usefulness of $\mathrm{NH}_{4} \mathrm{Cl}$ in preventing mountain sickness. Furthermore, the uncompensated acidosis produced by the drug in displacing the oxygen dissociation curve to the right would tend to neutralize the effect of the increased oxygen pressure in the blood.

Notwithstanding these considerations, a practical test seemed worth while. This test was performed in Peru. Of the 12 members who made up the party, 6 took $\mathrm{NH}_{4} \mathrm{Cl}$ in the doses stated under "Procedure."

Proof that this method of administering $\mathrm{NH}_{4} \mathrm{Cl}$ resulted in a significant decrease in alkaline reserve and in alveolar ventilation over the critical
TABLE III

Effects of $\mathrm{NH}_{4} \mathrm{Cl}$ on blood and alveolar ventilation on normal subjects at sea level

5 grams were ingested after each meal on the first day. Blood was drawn on the morning of the first day and 24 and 30 hours later. The results for the 3 specimens are in chronological order for each individual.

\begin{tabular}{|c|c|c|c|c|c|c|c|}
\hline \multirow{2}{*}{ Subject } & \multicolumn{2}{|c|}{$\begin{array}{l}\text { Alveolar } \\
\text { air }\end{array}$} & \multicolumn{3}{|c|}{$\begin{array}{c}\text { Equilibrated } \\
\text { oxygenated blood }\end{array}$} & \multirow{2}{*}{$\begin{array}{l}\text { Calcu- } \\
\text { lated } \\
\text { arte- } \\
\text { rial } \\
\text { pH. }\end{array}$} & \multirow{2}{*}{$\begin{array}{c}\text { Total } \mathrm{CO}_{2} \\
\text { of oxygenated } \\
\text { blood, when } \\
\mathrm{pCO}_{2}=40 \mathrm{~mm} .\end{array}$} \\
\hline & $\mathrm{pCO}_{2}$ & $\mathrm{pO}_{2}$ & $\mathrm{pCO}_{2}$ & $\begin{array}{l}\text { Total } \\
\mathrm{CO}_{2}\end{array}$ & $\mathrm{HbO}_{2}$ & & \\
\hline & $\underset{H \boldsymbol{g}}{\operatorname{mm}}$ & $\operatorname{mm}_{\mathrm{H}}$ & $\underset{H_{\boldsymbol{g}}}{\operatorname{mm}_{1}}$ & m.eq. & $m M$ & & m.eq. \\
\hline Dill. . & $\begin{array}{l}41.8 \\
38.3 \\
39.7\end{array}$ & $\begin{array}{l}106 \\
110 \\
106\end{array}$ & $\begin{array}{l}42.3 \\
42.1 \\
42.4\end{array}$ & $\begin{array}{l}22.5 \\
18.7 \\
20.8\end{array}$ & $\begin{array}{l}8.29 \\
8.38 \\
8.71\end{array}$ & $\begin{array}{l}7.38 \\
7.33 \\
7.36\end{array}$ & $\begin{array}{l}22.1 \\
18.3 \\
20.3\end{array}$ \\
\hline Forbes.... & $\begin{array}{l}42.6 \\
40.2 \\
40.3\end{array}$ & $\begin{array}{r}96 \\
103 \\
98\end{array}$ & $\begin{array}{l}42.0 \\
40.9 \\
38.3\end{array}$ & $\begin{array}{l}21.5 \\
18.2 \\
17.9\end{array}$ & $\begin{array}{l}9.09 \\
8.80 \\
8.69\end{array}$ & $\begin{array}{l}7.36 \\
7.30 \\
7.30\end{array}$ & $\begin{array}{l}20.7 \\
18.0 \\
18.1\end{array}$ \\
\hline Edwards. . & $\begin{array}{l}41.6 \\
38.0 \\
35.9\end{array}$ & $\begin{array}{r}99 \\
103 \\
105\end{array}$ & $\begin{array}{l}41.5 \\
39.6 \\
38.8\end{array}$ & $\begin{array}{l}21.0 \\
17.2 \\
17.2\end{array}$ & $\begin{array}{l}9.30 \\
9.58 \\
9.71\end{array}$ & $\begin{array}{l}7.36 \\
7.30 \\
7.32\end{array}$ & $\begin{array}{l}20.6 \\
17.2 \\
17.4\end{array}$ \\
\hline Keys..... & $\begin{array}{l}42.1 \\
38.8 \\
40.3\end{array}$ & $\begin{array}{r}101 \\
107 \\
98\end{array}$ & $\begin{array}{l}41.7 \\
38.4 \\
39.7\end{array}$ & $\begin{array}{l}21.7 \\
17.4 \\
18.9\end{array}$ & $\begin{array}{l}9.00 \\
8.90 \\
8.84\end{array}$ & $\begin{array}{l}7.37 \\
7.30 \\
7.33\end{array}$ & $\begin{array}{l}21.3 \\
17.7 \\
19.0\end{array}$ \\
\hline $\begin{array}{l}\text { F. Con- } \\
\text { solazio.. }\end{array}$ & $\begin{array}{l}39.3 \\
34.5\end{array}$ & $\begin{array}{l}103 \\
109\end{array}$ & $\begin{array}{l}43.4 \\
37.4 \\
39.0\end{array}$ & $\begin{array}{l}20.7 \\
16.3 \\
18.7\end{array}$ & $\begin{array}{l}9.48 \\
9.71 \\
9.53\end{array}$ & $\begin{array}{l}7.37 \\
7.32\end{array}$ & $\begin{array}{l}20.2 \\
17.0 \\
18.9\end{array}$ \\
\hline Daly..... & $\begin{array}{l}42.4 \\
35.2\end{array}$ & $\begin{array}{r}97 \\
120\end{array}$ & $\begin{array}{l}43.9 \\
37.7 \\
41.0\end{array}$ & $\begin{array}{l}21.5 \\
16.7 \\
18.9\end{array}$ & $\begin{array}{l}8.49 \\
9.26 \\
9.08\end{array}$ & $\begin{array}{l}7.35 \\
7.32\end{array}$ & $\begin{array}{l}20.4 \\
17.3 \\
18.8\end{array}$ \\
\hline $\begin{array}{l}\text { Mean } \\
\text { values. }\end{array}$ & $\begin{array}{l}41.6 \\
37.5 \\
39.0\end{array}$ & $\begin{array}{l}100 \\
109 \\
102\end{array}$ & $\begin{array}{l}42.5 \\
39.4 \\
39.9\end{array}$ & $\begin{array}{l}21.5 \\
17.4 \\
18.7\end{array}$ & $\begin{array}{l}8.94 \\
9.10 \\
9.09\end{array}$ & $\begin{array}{l}7.37 \\
7.31 \\
7.33\end{array}$ & $\begin{array}{l}20.9 \\
17.6 \\
18.7\end{array}$ \\
\hline
\end{tabular}

period was obtained after our return to Boston. Six subjects were given the same quantity at the same rate. Studies were made of the alveolar air and properties of the blood in the morning before beginning ingestion, the following morning, and the following afternoon. The results are shown in Table III. For comparison, the level of the $\mathrm{CO}_{2}$ curve of oxygenated blood of fully acclimatized men at various altitudes is shown in Table IV. It appears 'that the reduction in available alkali accomplished in 24 hours by the administration of $\mathrm{NH}_{4} \mathrm{Cl}$ is approximately equal to that established by normal men after gradual (but incomplete) acclimatization to an altitude of about 5000 meters. Therefore, if alkaline reserve is closely related to mountain sickness, as has been claimed, one would expect significant benefits 
TABLE IV

$\mathrm{CO}_{2}$ of oxygenated blood at $\mathrm{pCO}_{2}=40 \mathrm{~mm}$.

Results in m.eq. per liter

\begin{tabular}{|c|c|c|c|c|c|c|}
\hline Name & $\begin{array}{c}\text { Sea } \\
\text { level }\end{array}$ & $\begin{array}{c}\text { Chuqui } \\
2810 \\
\text { meters }\end{array}$ & $\begin{array}{c}\text { Ollagule } \\
3660 \\
\text { meters }\end{array}$ & $\begin{array}{c}\text { Montt } \\
4710 \\
\text { meters }\end{array}$ & $\begin{array}{l}\text { Quilcha } \\
5340 \\
\text { meters }\end{array}$ & $\begin{array}{l}\text { Punta } \\
6140 \\
\text { meters }\end{array}$ \\
\hline \multicolumn{7}{|c|}{ Members of expedition } \\
\hline 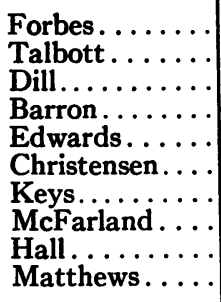 & $\begin{array}{l}22.4 \\
21.9 \\
22.2 \\
20.9 \\
21.5 \\
21.6 \\
22.3 \\
21.7 \\
20.4\end{array}$ & $\begin{array}{l}19.4 \\
19.2 \\
20.7 \\
19.2 \\
18.4 \\
19.1 \\
18.2 \\
19.1 \\
18.8 \\
19.2\end{array}$ & $\begin{array}{l}17.6 \\
18.8 \\
18.9 \\
\\
21.6 \\
19.4\end{array}$ & $\begin{array}{l}19.3 \\
18.8 \\
19.8 \\
18.7 \\
18.4 \\
19.9 \\
17.4 \\
18.3 \\
18.0 \\
19.3\end{array}$ & $\begin{array}{l}17.3 \\
17.7 \\
18.7 \\
19.2 \\
16.9 \\
18.5 \\
17.2 \\
17.6 \\
17.1 \\
17.5\end{array}$ & $\begin{array}{l}16.2 \\
16.0 \\
15.2^{*} \\
15.1 \\
13.8^{*} \\
15.7 \\
16.5 \\
17.1 \\
16.8\end{array}$ \\
\hline & 21.7 & 19.1 & 19.2 & 18.8 & 17.8 & 16.2 \\
\hline
\end{tabular}

Residents

\begin{tabular}{|c|c|c|}
\hline 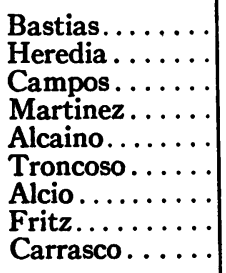 & $\begin{array}{r}18.0 \\
18.3\end{array}$ & $\begin{array}{l}16.2 \\
14.8 \\
14.8 \\
17.4 \\
15.0 \\
15.6 \\
15.3\end{array}$ \\
\hline Average... & & 15.9 \\
\hline
\end{tabular}

* After $\mathrm{NH}_{4} \mathrm{Cl}$ ingestion. Not included in the average.

from the administration of $\mathrm{NH}_{4} \mathrm{Cl}$ as it was carried out in Peru.

In Table $\mathrm{V}$ are given the alveolar $\mathrm{pO}_{2}$ and $\mathrm{pCO}_{2}$ of the members of the party from whom reliable samples were obtained. There was an increase in the alveolar $\mathrm{pO}_{2}$ of those who took $\mathrm{NH}_{4} \mathrm{Cl}$, and the average $\mathrm{pO}_{2}$ was higher (49.6 $\mathrm{mm}$. $\mathrm{Hg}$ ) than those of Hurtado (45.0) and Barron (47.0), both thoroughly acclimatized to high altitudes. In spite of this increase in the $\mathrm{pO}_{2}$ of the alveolar air, of the 6 subjects who took $\mathrm{NH}_{4} \mathrm{Cl}$, one, Montoya, became critically ill at 4140 meters, and 2 more became ill in Ticlio; i.e., half of those who had taken $\mathrm{NH}_{4} \mathrm{Cl}$ had mountain sickness. Of the other 6 members, who had not taken $\mathrm{NH}_{4} \mathrm{Cl}, 2$ had mountain sickness, one in Ticlio and the other on his way down. It should be emphasized that the three subjects who had taken $\mathrm{NH}_{4} \mathrm{Cl}$ and had mountain sickness had been in high altitudes previously with no ill effects. The gastric disturbances frequently produced by the drug might have accelerated the onset of the symptoms.

\section{DISCUSSION}

Although there is general agreement with Paul Bert's contention that the fundamental cause of mountain sickness is oxygen want, its mechanism is still obscure. In fact, Redfield's statement in 1922 (15) that in mountain sickness " each case is an individual story and up to the present no one has been able to predict who will and who will not be affected," as well as Loewy's remarks (16) made ten years later that "ihre Aetiologie jedoch ist durch neuste Beobachtungen eher dunkler geworden als aufgehellt," may still be repeated.

The alveolar air and the arterial oxygen saturations which we determined in subjects suffering from mountain sickness have revealed only that in rapid ascents up to 4700 meters the development of mountain sickness has no simple dependence on the arterial oxygen saturation and the alveolar oxygen pressure. Haldane's suggestion that diminution in the alkaline reserve by $\mathrm{NH}_{4} \mathrm{Cl}$ ingestion might hasten acclimatization is not borne out ; our experience indicates that $\mathrm{NH}_{4} \mathrm{Cl}$ offers a handicap rather than an advantage.

Since mountain sickness may be due to diminished oxygen utilization by certain tissues, in particular by the central nervous system, the factors concerned with the maintenance of a suitable oxygen supply to the tissues may be stated. These factors are essentially two: the vascular oxygen transport system (blood hemoglobin), whose efficiency is regulated by the arterial oxygen capacity and saturation and by the alveolar $\mathrm{pO}_{2}$; and the

TABLE $V$

Alveolar air in Lima and Ticlio

\begin{tabular}{|c|c|c|c|c|c|c|}
\hline \multirow[t]{2}{*}{ Name } & \multicolumn{2}{|c|}{$\begin{array}{c}\text { Lima, } \\
\text { barometric } \\
\text { pressure } \\
752 \mathrm{~mm} . \\
\mathbf{H g}\end{array}$} & \multicolumn{4}{|c|}{ Ticlio, barometric pressure 432 (4740 meters) } \\
\hline & pOs & $\mathrm{pCO}_{2}$ & $\mathrm{pO}_{2}$ & $\mathrm{pCO}_{2}$ & $\mathrm{NH}_{4} \mathrm{Cl}$ & Physical condition \\
\hline $\begin{array}{l}\text { Sandoval.. } \\
\text { Cordova... } \\
\text { Aldazabar. } \\
\text { Montaya.. }\end{array}$ & $\begin{array}{l}105.9 \\
103.0 \\
104.0 \\
103.9\end{array}$ & $\begin{array}{l}33.6 \\
36.6 \\
35.6 \\
34.9\end{array}$ & $\begin{array}{l}53.9 \\
49.8 \\
50.9\end{array}$ & $\begin{array}{l}23.9 \\
26.9 \\
24.8\end{array}$ & $\begin{array}{l}\text { Yes } \\
\text { Yes } \\
\text { Yes } \\
\text { Yes }\end{array}$ & $\begin{array}{l}\text { IIl. Mountain sickness } \\
\text { Good } \\
\text { Ill. Mountain sickness } \\
\text { III. Mountain sickness } \\
\text { (Left injCasapalca) }\end{array}$ \\
\hline $\begin{array}{l}\text { Tincopa... } \\
\text { Guzman ... } \\
\text { Prieto.... } \\
\text { A. Barron. } \\
\text { Hurtado.. } \\
\text { E. S. G. } \\
\text { Barron. . }\end{array}$ & \begin{tabular}{|l|}
102.2 \\
100.0
\end{tabular} & $\begin{array}{l}37.1 \\
38.0\end{array}$ & $\begin{array}{l}49.5 \\
44.1 \\
45.0 \\
47.0\end{array}$ & $\begin{array}{l}26.4 \\
30.1 \\
29.7 \\
28.3\end{array}$ & $\begin{array}{l}\text { Yes } \\
\text { Yes } \\
\text { None } \\
\text { None } \\
\text { None } \\
\text { None }\end{array}$ & $\begin{array}{l}\text { Good } \\
\text { Good Mountain sickness } \\
\text { Ill. Mood } \\
\text { Good } \\
\text { Good }\end{array}$ \\
\hline
\end{tabular}


tissue oxygen transport system (myoglobin and part of the cytochrome complex), whose efficiency is regulated by the blood flow, the state of the capillaries, etc. The studies of Monge, Encinas, Hurtado and Heraud (3) and of Hurtado (17) on the dwellers of the high Andes, and those of the Chilean expedition, have shown that normal life is possible with an arterial oxygen saturation as low as 70 per cent. These studies suggest that undue importance has been given to the vascular oxygen transport system. Since mountain sickness may occur when the vascular oxygen transport system is still within normal limits, it is suggested that the tissue oxygen transport system plays an important rôle in determining the appearance of mountain sickness, because it contains and transports the molecular oxygen which will be immediately utilized by the oxidizing enzymes, i.e., the enzymes concerned with cellular respiration. Little is known of the properties of this system. However, Theorell's brilliant contribution (18) has shown that the oxygen dissociation constant of horse myoglobin at $\mathrm{pH} 7.46$ is $3.26 \mathrm{~mm} . \mathrm{O}_{2}$; i.e., the myoglobin, at equal hydrogen ion concentration and temperature, has six times as great an affinity for 'oxygen as horse hemoglobin has; and Millikan reports (19) that myoglobin combines with oxygen several times as fast as hemoglobin. This relation between the affinity for oxygen (as expressed by the dissociation constants) and the rate of combination in these two systems is of great physiological importance. The same relation between free energy and rates of reaction has been found by Barron (20) to exist in a number of oxidation processes of biological importance. The existence of cytochrome in the heart, liver, and brain of mammalians has been reported by Cohen and Elvehjem (21). In sudden ruptures of equilibrium conditions (mountain sickness) this relation might influence the rate of diffusion of oxygen from the vascular oxygen transport system to the tissue oxygen transport system. Other factors which probably take part in the regulation of oxygen passage from the vascular system to the tissue transport system are an increased blood flow, as reported by Grollman (22), and dilatation of the capillaries.

\section{CONCLUSIONS}

The appearance of acute mountain sickness is not closely dependent upon the degree of arterial oxygen saturation and the alveolar air oxygen pressure, down to certain limits. Acute mountain sickness is not prevented by diminishing the alkaline reserve of the blood, as shown by the failure of ammonium chloride to prevent it in a rapid ascent from sea level to 4740 meters. The tissue oxygen transport system (myoglobin and part of the cytochrome complex) probably plays an important rôle in mountain sickness.

\section{PROTOCOLS OF THE EXPERIMENTS}

Members of the party who developed acute mountain sickness on the trip to Ticlio

Number 1. Montoya. Nurse, 26 years. Born in Arequipa (2280 meters). Had passed through Ticlio before with no ill effects. On arrival at Casapalca (4140 meters) he became extremely ill. He was very pale, felt chills and such severe dizziness that he could not walk, vomited, and had to be taken to the hospital on a stretcher. No samples of blood or alveolar air were taken. At the hospital he was given oxygen, and at 9:00 p.m., when we returned to Casapalca, he was feeling better and returned with us to Lima. He had taken $\mathrm{NH}_{4} \mathrm{Cl}$, which he felt sure was the cause of his illness.

Number 2. Sandoval. Student, 24 years. Born in Huari (3160 meters). Had crossed the Andes on horseback at heights of 4800 meters several times with no ill effects. On arriving at Ticlio he felt very cold, was extremely pale, complained of dizziness and nausea, and finally vomited. After resting in bed he felt better. He had taken $\mathrm{NH}_{4} \mathrm{Cl}$ and felt certain that it made him ill.

Number 3. Aldazabar. Nurse, 25 years. Born in Lima. Had been repeatedly at high altitudes. In Ticlio he felt extremely cold, had nausea, headache, dizziness, ringing in the ears. He was continuously shivering, so that samples of alveolar air could not be taken. He had taken $\mathrm{NH}_{4} \mathrm{Cl}$.

Number 4. Prieto. Student, 24 years. Born in Arequipa. Had never been in altitudes higher than Arequipa. From San Mateo on he felt headache and dizziness. In Casapalca he began to 
feel weak. At Ticlio, while walking to the engineer's house, he felt still weaker. At the house, he felt dizzy and faint; had nausea, vomiting, chills, extreme pallor, headache, and ringing of the ears. He was put to bed. His pulse was 88 , rhythmic and vigorous. During the return to Lima, he began to feel ill again, at about 2100 meters, and vomited copiously. This was his first ascent to so high an altitude. He had taken no $\mathrm{NH}_{4} \mathrm{Cl}$.

Number 5. A. G. Barron. Member of the faculty in the Medical School of Lima, 33 years. Born in Huari. Extremely susceptible to mountain sickness. One week previously he had come by car along this road and had had to stop in Matucana (2370 meters) because of headache and dyspnea. He had had mountain sickness when passing through Ticlio by train on two previous occasions. In Ticlio he was feeling dyspneic and had tachycardia (pulse 128). On the way down, at about 2700 meters, he felt headache and nausea, and vomited. No blood sample could be taken. He had taken no $\mathrm{NH}_{4} \mathrm{Cl}$.

The other members of the party felt no ill symptoms; nor did the three drivers. Edwards, Hurtado and E. S. G. Barron worked steadily in Ticlio from 4:45 p.m. to 8:30 p.m., taking the blood and air samples. Edwards and Barron had recently been in the Chilean Andes, and Hurtado goes through Ticlio every other week to Morococha (4500 meters).

\section{BIBLIOGRAPHY}

1. Bert, P., La Pression Barometrique. Paris, 1878.

2. Acosta, Jose, Historia natural y moral de las Indias en que se trata de cosas notables del cielo, de los elementos, metales, plantas y animales. Barcelona, 1569.

3. Monge, C. A., Encinas, A., Hurtado, A., and Heraud, C., La Enfermedad de los Andes. Informe Fac. Medicina, Lima, 1928.

4. Douglas, C. B., Haldane, J. S., Henderson, Y., and Schneider, E. C., Physiological observations made on Pike's Peak, Colorado, with special reference to adaptation to low barometric pressures. Phil. Tr. Roy. Soc., London, B., 1913, 203, 185.

5. Barcroft, J., Binger, C. A., Bock, A. V., Doggert, J. H., Forbes, H. S., Harrop, G., Meakins, J. C., and Redfield, A. C., Observations upon the effect of high altitude on the physiological processes of the human body, carried out in the Peruvian Andes, chiefly at Cerro de Pasco. Phil. Tr. Roy. Soc., London, B., 1922, 211, 351.

6. Dill, D. B., Christensen, E. H., and Edwards, H. T., Gas equilibria in the lungs at high altitudes. Am. J. Physiol., 1936, 115, 530.

7. Keys, A., Hall, F. G., and Barron, E. S. G., The position of the oxygen dissociation curve of human blood at high altitude. Am. J. Physiol., 1936, 115, 292.

8. Hall, F. G., The effect of altitude on the affinity of hemoglobin for oxygen. J. Biol. Chem., 1936, 115, 485.

9. Barcroft, J., Features in the Architecture of Physiological Function. University Press, Cambridge, 1934.

10. Dill, D. B., Talbott, J. H., and Edwards, H. T., Studies in muscular activity; VI. Response of several individuals to a fixed task. J. Physiol., 1930, 69, 267.

11. Haldane, J. S., and Priestley, J. G., Respiration. Clarendon Press, Oxford, 1935, $2 d$ ed.

12. Smythe, F. S., Kamet Conquered. Victor Gollancz, Ltd., London, 1932.

13. Douglas, C. G., Greene, C. R., and Kergin, F. G., The influence of ammonium chloride on adaptation to low barometric pressures. J. Physiol., 1933, 78, 404.

14. Fölling, A., On the mechanism of the ammonium chloride acidosis. Acta med. Scandinav., 1929, 71, 221.

15. Redfield, A. C., Accommodation to the anoxemia of high altitudes. Boston M. and S. J., 1922, 187, 841.

16. Loewy, A., Einiges Neure über Bergkrankheit. Schweiz. med. Wchnschr., 1932, 62, 1173.

17. Hurtado, A., Studies at high altitude. Blood observations on the Indian natives of the Peruvian Andes. Am. J. Physiol., 1932, 100, 487.

18. Theorell, H., Krystallinisches Myoglobin. V. Die Sauerstoffbindungskurve des Myoglobins. Biochem. Ztschr., 1934, 268, 73.

19. Millikan, G. A., The kinetics of muscle haemoglobin. Proc. XV International Physiological Congress at Leningrad, Moscow, 1935, p. 275.

20. Barron, E. S. G., The rate of autoxidation of oxidation-reduction systems and its relation to their free energy. J. Biol. Chem., 1932, 97, 287.

21. Cohen, E., and Elvehjem, C. A., The relation of iron and copper to the cytochrome and oxidase content of animal tissues. J. Biol. Chem., 1934, 107, 97.

22. Grollman, A., Physiological variations of the cardiac output of man. VII. The effect of high altitude on the cardiac output and its related functions; an account of experiments conducted on the summit of Pike's Peak, Colorado. Am. J. Physiol., 1930, 93, 19. 